\title{
CULTURAL ENVIRONMENTALISM AND BEYOND
}

\author{
JAMES BOYLE*
}

\section{I \\ INTRODUCTION}

It is hard to explain how honored I was when Larry Lessig and his colleagues at Stanford organized this conference around some of my ideas-or more accurately, around a set of ideas for which they gave me greater credit than I deserved. This kind of thing generally happens when one is either dead or retiring (I am hoping that the contributors do not have some knowledge I lack about the imminence of either of those events). The event was doubly humbling. The scholars who agreed to write for this volume are a remarkable group whose work I admire greatly, while Larry's own scholarship and work as a public intellectual are also a great inspiration to me-he is clearly the one whose work deserves a symposium, if anyone's does.

The contributions to the symposium include four main articles that engage in different ways and degrees with my work and with the idea of cultural environmentalism, commentaries on those articles, and, at the end, two papers that evolved from commentaries but that are no longer directed towards the articles on which they originally commented. ${ }^{1}$ I could not hope to respond to everything in the volume point by point, and I am not going to try. Instead, I will offer my own thoughts on the failings, limitations, occasional promise, and possible future of the ideas discussed in this symposium-both the work on cultural environmentalism and the surrounding ideas on authorship, the rhetoric of economic analysis, the structure of intellectual property scholarship, and the jurisprudence of the public domain. Where appropriate, I will try to link my comments back to the individual articles and comments in this symposium.

Copyright (C) 2007 by James Boyle. Anyone may make verbatim copies of this article for noncommercial purposes so long as the following notice is retained on all publicly distributed copies:

(C) 2007 James Boyle. Originally published in Symposium, Cultural Environmentalism @ 10, 70

Law \& Contemp. Probs. (James Boyle \& Lawrence Lessig, eds., Spring 2007). Licensed under the Creative Commons Attribution-NonCommercial-Sharealike License. To view a copy of this license, visit http://creativecommons.org/licenses/by-nc-sa/3.0/ or send a letter to Creative Commons, 543 Howard Street, 5th Floor, San Francisco, California, 94105, USA.

This article is also available at http://law.duke.edu/journals/lcp.

* William Neal Reynolds Professor of Law, Duke Law School.

1. The fine papers by Siva Vaidhyanathan, The Anarchist in the Coffee House: A Brief Consideration of Local Culture, the Free Culture Movement, and Prospects for a Global Public Sphere, 70 LAW \& CONTEMP. Probs. 205 (Spring 2007), and Mark Lemley, Should A Licensing Market Require Licensing?, 70 LAW \& CONTEMP. PROBS. 185 (Spring 2007), respectively. 


\title{
MAKING VISIBLE THE INVISIBLE
}

\begin{abstract}
You will recall my work here, such as it has been .... None of it does more than mark time. Repetitive and disconnected, it advances nowhere. Since indeed it never ceases to say the same thing, it perhaps says nothing. It is tangled up into an indecipherable, disorganised muddle. In a nutshell, it is inconclusive. Still, I could claim that after all these were only trails to be followed, it mattered little where they led; indeed, it was important that they did not have a predetermined starting point and destination. They were merely lines laid down for you to pursue or to divert elsewhere, or re-design as the case might be. They are, in the final analysis, just fragments, and it is up to you or me to see what we can make of them. For my part, it has struck me that I might have seemed a bit like a whale that leaps to the surface of the water disturbing it momentarily with a tiny jet of spray and lets it be believed, or pretends to believe, or wants to believe, or himself does in fact believe, that down in the depths where no one sees him any more, where he is no longer witnessed nor controlled by anyone, he follows a more profound, coherent and reasoned trajectory. Well, anyway, that was more or less how I at least conceived the situation; it could be that you perceived it differently. ${ }^{2}$
\end{abstract}

Apart from the sneaking feeling that "indecipherable, disorganized muddle" describes my work better than his, I have little in common with Foucault. Still, a symposium is the perfect place for indulging oneself in the delusion of deeper coherence that he describes. I shall not resist the temptation.

Cultural environmentalism is an idea, an intellectual and practical movement, that is supposed to be a solution to a set of political and theoretical problems - an imbalance in the way we make intellectual property policy, a legal regime that has adapted poorly to the way that technology has broadened its ambit, and perhaps most importantly a set of mental models, economic nostrums, and property theories that each have a public-domain-shaped hole at their center.

The comparison I drew between the history of environmentalism and the state of intellectual property policy had a number of facets. The environmental movement had "invented" the concept of the environment and used it to tie together a set of phenomena that would otherwise seem very separate. In doing so, it changed perceptions of self-interest and helped to form coalitions where none had existed before. The process of the invention of environmentalism, however, was no mere semantic sleight of hand. Intellectually, it built on the insights of earth science about the fragile interconnections of the ecology and on the Pigouvian analysis of economic externalities ${ }^{3}$ - pollution about which we

2. Michel Foucault, Two Lectures, in Power/Knowledge: Selected InTerviews AND OTHER WRITINGS, 1972-1977, at 78-79 (Colin Gordon ed. \& Colin Gordon et al. trans., 1980).

3. See Arthur C. Pigou, Divergences Between Marginal Social Net Product and Marginal Private Net Product, in THE ECONOMICS OF Welfare 173 (4th ed. 1978) ("The source of the general divergences between the values of marginal social and marginal private net product that occur under simple competition is the fact that, in some occupations, a part of the product of a unit of resources consists of something, which, instead of coming in the first instance to the person who invests the unit, comes instead, in the first instance (i.e. prior to sale if sale takes place), as a positive or negative item, to other people."), available at http://www.econlib.org/Library/NPDBooks/Pigou/pgEW1.html. Ironically, so far as I can find, Pigou does not use the word "externality." 
do not make rational decisions, because the cost is "invisible," for example. It offers a profound critique of an economic orthodoxy built on the assumption of perpetual growth. I argued that, in a similar way, we needed to make visible the invisible contributions of the public domain, the "eco-system services" performed by the under-noticed but nevertheless vital reservoir of freedom in culture and science. ${ }^{4}$ And, just as with environmentalism, we needed not only a semantic reorganization, or a movement devoted to a goal, but a set of conceptual and analytic tools.

\section{PROPERTY THEORY}

The environment was undervalued by a narrow and formalistic conception of property rights that ignored the effects of pollution and other activities on the collective ecology, not counting it as a legally cognizable harm. Similarly, there were areas in intellectual property law where the public domain was undervalued by an ideology of authorial romance, which assumed innovation sprang out of thin air - the great author needs no raw material for his creations. ${ }^{5}$ What was needed was a scholarly literature that provided a historical and critical analysis of the various ideologies of authorship and their effects on both the language and the doctrine of intellectual property law. Thanks to the work of scholars such as Peter Jaszi, Martha Woodmansee, and Mark Rose ${ }^{6}$-all of whom influenced my work greatly-that literature is now both rich and deep. Rebecca Tushnet's paper in this symposium, with its account of how fan fiction continues to elaborate on plot, character, and setting long after a work has been

4. As always, Jessica Litman provides the clearest and most down-to-earth example. Commenting on Rebecca Tushnet's engrossing paper on fan fiction, Rebecca Tushnet, Payment in Credit: Copyright Law and Subcultural Creativity, 70 LAW \& CONTEMP. PROBS. 135 (Spring 2007), Litman describes copyright's "balance between uses copyright owners are entitled to control and other uses they simply are not entitled to control." Jessica Litman, Creative Reading, 70 LAW \& CONTEMP. PROBS. 175, 175 (Spring 2007). That balance, she suggests, is not bug but feature. The spaces of freedom that exist in the analog world because widespread use is possible without copying are neither oversights nor temporarily abandoned mines of monopoly rent just waiting for a better technological-retrieval method. They are integral parts of the copyright system.

5. The blindness to raw materials does not always lead to overprotection, of course. In some cases, I argued, the lens of authorship might symmetrically lead us to "underprotect" or undervalue resources that are used as inputs for intellectual property-plant species, or ethnobotanical knowledge, for example - but which do not fit intellectual property law's requirement of individual, transformative activity. My argument was that this under- and overinclusiveness had costs both in terms of efficiency or innovation, and in terms of justice-distributive and otherwise. JAMES BOYLE, SHAMANS, SOFTWARE, AND SPLEENS: LAW AND THE CONSTRUCTION OF THE INFORMATION SOCIETY 119-43, 192-200 (1996). These parts of the analysis have attracted less attention.

6. Peter Jaszi, Toward a Theory of Copyright: The Metamorphoses of "Authorship," 41 DUKE L.J. 455 (1991); The CONSTRUCTION OF AUthorship: TEXTUAL APPROPRIATION IN LAW AND LITERATURE (Martha Woodmansee \& Peter Jaszi eds., 1994 ); MARK RosE, AUTHORS AND OWNERS: THE INVENTION OF COPYRIGHT (1993); Martha Woodmansee, The Genius and the Copyright: Economic and Legal Conditions of the Emergence of the "Author," 17 EIGHTEENTH-CENTURY STUD. 425 (1984). See also James Boyle, A Theory of Law and Information: Copyright, Spleens, Blackmail and Insider Trading, 80 CAL. L. REV. 1413 (1992) (noting prior copyright scholarship); BOYLE, supra note 5 (discussing prior intellectual-property scholarship). 
published or broadcast, is a particularly fine example of the practical conflicts between an ideal of authorial creation and control and the reality of the way in which creativity and culture weave author and reader together. ${ }^{7}$ This literature also continues to attract attention from those outside of the world of intellectual property. Susan Crawford's paper ${ }^{8}$ compares the rhetoric of romantic authorship in intellectual property to the rhetoric in a different areacommunications law and policy and the debate about "net neutrality." Her conclusion? "These two sets of arguments are strikingly parallel. The same battles are being played out again, but this time at the fundamental level of network transport. Again, a romantic figure is being used-this time, the romantic figure of the "network builder.","

Beyond the focus on authorial romance (which I still think to be important, if not as important as I did when I wrote Shamans, Software and Spleens ${ }^{10}$ ), we needed a better theory of the outside, the opposite of property-a legal realism for the public domain that rivals our sophistication about property itself. Here is a second area in which I would argue that the discipline has developed at remarkable speed. We have better alternative definitions of the public domain, as well as a sense of which perceived dysfunction in intellectual property each definition is implicitly responding to-the dangers of monopoly control, of high prices, of restriction of future innovation, and so on. ${ }^{11}$ We also have a

7. Tushnet, supra note 4 .

8. Susan P. Crawford, Network Rules, 70 LAW \& CONTEMP. ProbS. 51 (Spring 2007). The analogy is a tempting and provocative one. Like the author, the network builder can claim to have created something that was not there before. Thus, any property claim, by definition, does not impoverish society - or so goes the argument. Certainly, the claims about the need for strong property rights are similar. There are also important differences, however. Networks are unlike expressive goods in some of their economic characteristics, while the types of "romance" being used-Stakhanovite laborer, far-sighted investor versus Byronic visionary, or Proustian iconoclast-also differ. The key to the conception of the romantic author is that it is not a vision based on an amount of labor or capital, but one based on the idea of originality - of creation out of nothing. It is that originality - the expression of the unique persona of the creator - that provides both the moral warrant for the right and the basis for curtailing its operation to the boundaries of original expression alone. See Feist Publ'ns, Inc. v. Rural Tel. Serv. Co., 499 U.S. 340, 345 (1991) ("To qualify for copyright protection, a work must be original to the author."); BOYLE, supra note 5, at 56-59, 156. These are points that Julie Cohen's commentary makes with particular force. Julie E. Cohen, Network Stories 70 LAW \& CONTEMP. PROBS. 91 (Spring 2007). And as Cohen stresses, the only way to decide whether we wish to accept or to criticize the claims of the telecommunications companies is to "do the science"-to investigate empirically and clarify normatively the social goals and community formation that is enabled by a particular network structure. Id. at 91.

9. Crawford, supra note 8 , at 53 .

10. BOYLE, supra note 5 .

11. This is a point worth stressing. We do not have a single, unitary public domain, a single commons. There are competing and overlapping ones. See James Boyle, Foreword: The Opposite of Property?, 66 LAW \& CONTEMP. PROBS. 1, 29-32 (Winter/Spring 2003) [hereinafter The Opposite of Property?]. Definitions vary in their degree of "granularity." Does the public domain, for example, include only complete works, completely free, or does it include all the circumstantial privileges and limitations on intellectual-property rights - such as fair use, for example? Definitions also vary in the degree to which they focus on legal status or on ability to gain access-either without permission, or sometimes without fee. Thus, although we do need a theory of the public domain, our goal should not be "reifying the negative" (the critical phrase used by Edward Samuels to describe the futility of a theory of the public domain). See James Boyle, The Second Enclosure Movement and the Construction 
burgeoning literature on the notion of the commons-a concept, or cluster of concepts, that is often confused with the public domain, but that has important differences. ${ }^{12}$ This includes work on the "comedy of the commons" ${ }^{13}$ and the importance of "commons-based peer production." ${ }^{14}$ There is a particularly strong connection here to the environmental field where Elinor Ostrom's pathbreaking work on "governing the commons" has replaced the simplistic account of the tragedy of the commons with a more sophisticated discussion of the methods of regulating common pool resources. ${ }^{15} \mathrm{I}$ am particularly pleased at having persuaded Professor Ostrom to turn her focus to the intellectual commons, both in our public domain symposium and in a recent collection of essays on scholarly communication as a commons. ${ }^{16}$

But the developments here are not merely ones in commons theory. There has been a dramatic increase of institutional efforts to turn commons theory into commons practice, using the traditional tools of contract and license to create a commons through private agreement and technological implementation; the free and open-source software movements and Creative Commons - founded by the organizer of this symposium, Larry Lessig — are the obvious reference points here. Molly Shaffer Van Houweling's paper, Cultural

of the Public Domain, 66 LAW \& CONTEMP. PROBS. 33, 69-72 (Winter/Spring 2003) (citing Edward Samuels, The Public Domain in Copyright Law, 41 J. COPYRIGHT SoC'Y 137, 150 (1993)). Yes, we do need a better theory of the public domain, rather than just a laundry list of exceptions and limitations, but "better theory" does not equate to "single definition." Our goal should be to understand the goals of each particular definition of the public domain - the hopes and fears around which it is built, the way a particular public domain is actually the mirror image of the conception of intellectual property to which it responds, both formally and in terms of possible economic dysfunction. Just as we use the term property appropriately in very different ways, depending on our goal, so, too, with the public domain. See Boyle, The Opposite of Property?, supra, at 2 (explaining the different conceptions of commons). Pamela Samuelson's fine paper is particularly instructive on this point. Pamela Samuelson, Enriching Discourse on Public Domains, 55 DUKE L.J. 783 (2006).

12. To give a practical example, imagine you are concerned by the effects of patents and copyright over software. You might take the approach that the rights should be curtailed or limited. The public domain should be preserved or expanded. But you also might take the approach that some of the practical problems could be solved by a "commons"- by using intellectual-property rights and licenses to create a mutually reinforcing zone of freedom. Free and open-source software under the General Public License is the obvious example. That software is not in the public domain. Far from it-the enforceability of the license depends on the underlying copyrights to the code. But the software is being developed in a commons in which each participant is required to contribute their new contributions back into the common pool. For a different and more extended example, see Arti Rai \& James Boyle, Synthetic Biology: Caught Between Property Rights, the Public Domain and the Commons, PLoS BIOLOGY (forthcoming), available at http://eprints.law.duke.edu/archive/00001593/01/Synthetic Biology_PLOS_1031.pdf.

13. Carol M. Rose, The Comedy of the Commons: Custom, Commerce, and Inherently Public Property, 53 U. CHI. L. REV. 711, 711 (1986).

14. Yochai Benkler, Coase's Penguin, or, Linux and The Nature of the Firm, 112 YALE L.J. 369, 375 (2002); see also Yochai BENKLER, THE WEALTH OF NETWORKS (2006) (explaining the importance of "commons-based peer production").

15. ElinOR OSTROM, GOVERNING THE COMMONS: THE EvOlution OF INSTITUTIONS FOR COLLECTIVE ACTION (1990).

16. James Boyle, Mertonianism Unbound?: Imagining Free, Decentralized Access to Most Cultural and Scientific Material, in Understanding KNOWLEDGE AS A COMMONS 123 (Charlotte Hess \& Elinor Ostrom eds., 2006); Charlotte Hess \& Elinor Ostrom, Ideas, Artifacts, and Facilities: Information as a Common-Pool Resource, 66 LAW \& CONTEMP. PROBS. 111 (Winter/Spring 2003). 
Environmentalism and the Constructed Commons ${ }^{17}$ is a great window on this practice. She gives us a fascinating essay that explores both the benefits and failings of "conservation easements" on land on the one hand and the licensing commons on the other. ${ }^{18}$ The practical issues are numerous and convoluted. The theoretical issues, however, are even more interesting.

Consider the complexities involved in Van Houweling's subject matter. We have the use of license and property right to create a commons, a process of conceptual judo. There are clear theoretical differences between the public domain and the licensing commons. In the public domain, freedom is based on the absence of property rights. In the licensing commons, freedom is based on the preemptive exercise of the property rights by the rights holder in order to grant use privileges to users of the commons, and sometimes to bind those future users to add their own improvements back to the common pool. Which strategy is the best for achieving openness in particular areas? ${ }^{19}$ Then there are the questions this raises about rules on alienability and the effect on third parties and the differences between contract and license. There is also the issue whether we need to revisit any of the nostrums of property law or of contract law in the light of the commons-constructing enterprise. Professor Van Houweling's paper introduces all of these and more.

\section{IV}

\section{ECONOMICS}

Environmentalism used arguments about externalities to suggest that things not currently given economic "value" within the market system-for example, endangered species, or biodiversity-needed to have a price, or at least an economic quantification of damage assigned to them. The goal was to render them visible within our analysis. But was there also a cost to thinking this way? As Aldo Leopold described it,

One basic weakness in a conservation system based wholly on economic motives is that most members of the land community have no economic value....

When one of these non-economic categories is threatened, and if we happen to love it, we invent subterfuges to give it economic importance.

It is painful to read those circumlocutions today. ${ }^{20}$

Is there a similar danger in intellectual property law-that though the economic focus is both useful and necessary, we will end up distorting some of the concerns we are trying to express by setting them in the language of economic analysis? I would argue that there is. The problem is both internal

17. Molly Shaffer Van Houweling, Cultural Environmentalism and the Constructed Commons, 70

LAW \& CONTEMP. PROBS. 23 (Spring 2007).

18. Id. at 24 .

19. See Rai \& Boyle, supra note 12 , at 8 (discussing different strategies for achieving openness).

20. Aldo LeOpold, The Land Ethic, in A SAND County Almanac: With Essays on CONSERVATION 177 (Oxford Univ. Press ed., 2001) (1949). 
and external. If one looks inside the microeconomic analysis of information issues one finds it is considerably more indeterminate than our dear friends the economic analysts of law would have us believe. It is beset by fundamental contradictions, ${ }^{21}$ unjustified shifts of analytical baselines, ${ }^{22}$ and concealed assumptions. ${ }^{23}$ In short, it is more a compendium of extremely useful heuristics and reminders than an algorithmic resolution of policy disputes-a rhetoric rather than a science. Within this rhetoric, and within these conflicting baselines, our discipline plays itself out.

The basic division in the intellectual property field is between maximalists or high protectionists, on the one hand, and minimalists, or those with a concern about the public domain, on the other... The maximalists favor expansive intellectual property rights. They view exemptions and privileges on the part of users or future creators as a tax on rights holders and have considerable sympathy for thinly disguised "sweat-ofthe-brow" claims. They exhibit a kind of economic bipolar disorder: being deeply pessimistic about market functioning around potential public goods problems in the absence of intellectual property rights, and yet strikingly, even manically, optimistic about our ability to avoid transaction costs and strategic behavior "anticommons effects" that might be caused by the presence of intellectual property rights.

The minimalists have exactly the opposite set of attitudes. They start from the presumption that the baseline of American law is that "the noblest productions of the human mind are upon voluntary disclosure to others, free as the air to common use." Thus intellectual property rights, understood as "monopolies," look like dangerous state granted subsidies, which should be confined in amount and extent to the minimum demonstrably necessary. Minimalists exhibit their own bipolarity; in many cases they are optimistic about the ability of creators and innovators to gain returns on innovation without recourse to legal monopolies.... They are also relatively optimistic about technology; they see new technologies that lower the cost of copying, such as the internet or PCR, as providing benefits as well as costs to rights holders, so that every reduction in the cost of copying need not be met with a corresponding increase in the level of protection. On the other hand, the minimalists are deeply, almost tragically, pessimistic about the ability of rights holders to bargain around the potential inefficiencies and transaction costs that their rights introduce into the innovation process. Here, private action to avert potential market failure seems much harder, for some reason. ${ }^{24}$

Ironically, this stylized division between maximalists and minimalists has-at least in my view-contributed to a narrowness of our scholarly intellectual tools. As I argued in another context,

The minimalists are those with the strongest incentive to challenge the expansion of intellectual property rights .... Yet because of the structure of the rhetoric in the discipline, they are also those most committed to the claim that only utilitarian arguments about the encouragement of future innovation are legitimate parts of the

21. See BOYLE, supra note 5, at 35-40 (discussing fundamental contradictions in economic analysis).

22. See, e.g., id. at 84-87 (discussing errors in economic analysis regarding baselines).

23. See, e.g., id. at $62-68,87-88$ (discussing various assumptions in economic analysis); James Boyle, Cruel, Mean, or Lavish? Economic Analysis, Price Discrimination and Digital Intellectual Property, 55 VAND. L. REV. 2007, 2010-21 (2000) (discussing economic rhetoric in intellectual property).

24. James Boyle, Enclosing the Genome?: What the Squabbles over Genetic Patents Could Teach Us, in Perspectives on Properties of the Human Genome Project 97, 107-08 (F. Scott Kieff ed., 2003). 
discourse. Minimalists are used to fighting off covert "sweat-of-the-brow" claims, concealed appeals to natural right, and Hegelian notions of personality made manifest in expression-all deployed to argue that rights-holders should have their legally protected interests expanded yet again. Against these rhetorics, they insist on both constitutional and economic grounds that the reason to extend intellectual property rights can only be the promotion of innovation. ${ }^{25}$

At the same time, the definition of the "innovation" that we commit ourselves to promoting has itself been a surprisingly reductionist oneapparently consisting of that package of potential future goods, technologies, culture, and inventions it is reasonable to believe that current market participants would value the most, with the valuation depending on the existing distribution of wealth and of rights. By this definition, of course, the hair-loss drug is indeed a more valuable innovation than the cure for most tropical diseases. When correctives are offered to this perspective, they tend to be offered from outside the efficiency calculus - as matters of "justice" or "equity," rather than as criticisms of the definition of efficiency or innovation itself. Again, there is a parallel to the economic analysis of environmental issues, where the most profound critiques do not merely offer moral critiques of the logic of a consumption society based on perpetual growth, but argue that failure to realize the limits of such a macroeconomic strategy are failures of the economic analysis itself. ${ }^{26}$

So, to sum up, intellectual property scholarship has suffered from a focus on economic analysis alone, as opposed to the other potentially useful perspectives and-even within economic analysis-on a particularly narrow version of economics. This double narrowness in our scholarly focus is one that Aldo Leopold would have decried and that we should regret. But it is not an inevitable one, and this is a point that Arti Rai's fascinating essay ${ }^{27}$ makes particularly clear.

For some, the limitations and biases of conventional economic analysis are reasons to reject it and to turn away from a utilitarian framework. Madhavi Sunder's provocative paper, ${ }^{28}$ for example, argues that the failure of intellectual property to recognize the contributions of traditional and natural sources cannot be rectified by mere payment. She posits a non-monetizable, nonutilitarian benefit in terms of worth or dignity in having one's contribution labeled as the subject of an intellectual property right. This is a fascinating idea for empirical research. But is this in fact the way intellectual property rights are perceived? Might a different name for a claim on a payment stream produce the same effects? It also raises an important conceptual question. We know from

\section{Id. at 119 .}

26. See, e.g., Herman E. Daly, Beyond Growth: The Economics of Sustainable DEVELOPMENT (1996) (explaining the failure of economic analysis).

27. Arti Rai, The Ends of Intellectual Property: Health as a Case Study, 70 LAW \& CONTEMP. PROBS. 125 (Spring 2007).

28. Madhavi Sunder, The Invention of Traditional Knowledge, 70 LAW \& CONTEMP. PROBS. 97 (Spring 2007); see also William Fisher, Two Thoughts About Traditional Knowledge, 70 LAW \& CONTEMP. PROBS. 131 (Spring 2007). 
300 years of experimentation with intellectual property rights that it is possible to harm as well as help by granting a new right. To be sure, this has not caused developed-world legislatures to spend much time looking at empirical evidence of costs and benefits. ${ }^{29}$ Does this mean that we should be equally free with our intuitions in the developing world? Or do we assume that artificially created monopolies can have even deadlier effects in economies where the margin for error is slim? I would argue that broadening the conceptual framework of intellectual property should not mean giving up the attempt to weigh costs and benefits. At some point, the costs of a new right are too high.

How does one broaden the utilitarian calculation without giving up entirely the chastening effect of the questions, "But does it work?" and "Does it do more harm than good?" Of course, definitions of harm and good will be debatable and perhaps incommensurable. But we will be the poorer both conceptually and practically if we do not attempt to model them, expose our assumptions, and make trade-offs explicit.

Arti Rai's paper offers one answer. Drawing on welfare economics, she points out the great limitations of some conventional measures of efficiency. As I suggested earlier, the hair-loss treatment is actually "more valuable" than the treatment of malaria if we base our valuation on ability and willingness to pay. Rai gives the example of an alternative measure that is actually used in making health-care decisions-QALY, or quality-adjusted life years. ${ }^{30}$ Should we spend scarce resources on developing this drug for the treatment of schistomiasis or this drug for the treatment of Chagas Disease? Assume neither population has the ability to pay. Quantifying benefits in terms of QALY does not give us a neutral measure of worth, of course. But it does expose the value judgments being made and give us a yardstick other than intuition or anecdote for measuring effects. Thus, Rai argues that rather than giving up on economic analysis, we should seek other ways to broaden its scope.

Do innovations such as QALY answer Leopold's critique? Do we have our intellectual "substitutes for a land ethic"? No, not completely. Welfare economics or behavioral economics stretch the boundaries of utilitarian analysis but remain firmly within it. That framework will always exist in tension with approaches that challenge utilitarianism at its root, as Leopold does-though as I have argued elsewhere, there is much to be said for insoluble theoretical tension. ${ }^{31}$ If there is a larger goal here, it is not resolving the tension, but seeking to retain some of the insights of each tradition, melding critical theory and utilitarian analysis into something broader and more self-reflective. And the

29. James Boyle, A Natural Experiment, Fin. Times Online, Nov. 22, 2004, http://www.ft.com/cms/s/4cd4941e-3cab-11d9-bb7b-00000e2511c8.html; James Boyle, Two Database Cheers for the EU, FIN. TIMES ONLINE, Jan. 2, 2006, http://www.ft.com/cms/s/99610a50-7bb2-11daab8e-0000779e2340.html; James Boyle, Deconstructing Stupidity, Fin. Times OnLINE, Apr. 21, 2005, http://www.ft.com/cms/s/39b697dc-b25e-11d9-bcc6-00000e2511c8.html.

30. Rai, supra note 27, at 127.

31. James Boyle, Anachronism of the Moral Sentiments? Integrity, Postmodernism, and Justice, 493 STAN. L. REV. 493 (1999). 
double insistence on exposing both one's normative assumptions and the empirical consequences of one's prescriptions seems like a good way to expand the horizons of intellectual property scholarship without turning it into mush in the process. Again, I think we can take some comfort from the dialectic between environmental thinking and economic analysis.

\section{$\mathrm{V}$ \\ THE INSTITUTIONAL ECOLOGY}

The next thing I think we can learn from environmentalism goes not to property theory, not to economic analysis, but to the construction of institutions and the broadening of the debate on policy.

In the article that coined the environmental analogy, ${ }^{32}$ I claimed that intellectual property policy was seen as a contract struck between industry groups-something that was technical, esoteric and largely irrelevant to individual citizens, except in that they were purchasers of the products that flowed out of the system. Whether that view had ever been tenable, it was not so in a digital age. Instead, I argued that we needed a "politics of intellectual property" ${ }^{33}$ modeled on the environmental movement to create a genuine and informed political debate on intellectual property policy. So far, I have concentrated on the theoretical and academic tools such a debate would needfocusing particularly on property theory and on economic analysis and its limits. But I also argued that if there was to be a genuinely democratic politics of intellectual property, we would need an institutional diversity in the policymaking debate that was comparable to that of the environmental movement.

Environmentalism presents us with a remarkable diversity of organizational forms and missions. We have Greenpeace, the Environmental Legal Defense Fund, groups of concerned scientists, and the Audubon Society, each with its own methods, groups of supporters, and sets of issues. Yet we also have local and pragmatic coalitions to save a particular bit of green space, using the private tools of covenants and contracts that Professor Van Houweling's paper describes. $^{34}$ The organization-building challenge of the last ten years was to begin the process of replicating that institutional diversity in the world of intangible property.

It is in this area that I think we can see the most marked developments. Ten years ago, civil society had little to offer in terms of groups that represented anything other than an industry position on intellectual property, still less one that took seriously the preservation of the public domain or the idea that intellectual property policy was a matter of balance, rather than simple

32. James Boyle, A Politics of Intellectual Property: Environmentalism for the Net?, 47 DUKE L.J. 87 (1997).

33. Id. at 89 .

34. Van Houweling, supra note 17. 
maximization of rights. There were the librarians and a few academics. That was about it. This position has changed radically.

There are academic centers that concentrate on the theoretical issues discussed in this symposium. Closest to my heart is the Center for the Study of the Public Domain at Duke,$^{35}$ which held the first conference on the public domain in 2001. ${ }^{36}$ But the Stanford Center for Internet and Society, the Berkman Center, American University, and a variety of others all spend substantial amounts of time and intellectual energy on the issue of the balance between intellectual property and the public domain. Projects range from discussions of alternative compensation systems ${ }^{37}$ and treatment of orphan works under copyright law $^{38}$ to educational efforts aimed at bringing artists into the debate about the law that shapes their conditions of creativity, ${ }^{39}$ and pro bono-litigation..$^{40}$ In the sciences, organizations such as Duke's Center for Public Genomics $^{41}$ use interdisciplinary tools including phenomenologies, case histories, economic analysis, and empirical research in seeking to calibrate the balance between proprietary tools and open science, private gain, and public benefit. What is more, the products of these Centers are disseminated beyond academia - a point I will return to in a moment. Academic work also has an immediate impact on individuals. We now have intellectual property law clinics that focus on law-reform efforts as well as on representing individuals. The Samuelson Clinic at Boalt Hall and the Samuelson-Glushko Clinic at American University deserve special mention, as, again, does the Stanford Center for Internet and Society. ${ }^{42}$

Beyond academic work, there are organizations that have dedicated themselves to advocacy and to litigation around the themes of preservation of the public domain, defense of limitations and exceptions in copyright, and the protection of free speech from the effects of intellectual property regulation of both content and communications infrastructure. The Electronic Frontier Foundation did exist ten years ago, but its coverage of intellectual property

35. The Center's website can be found at http://www.law.duke.edu/cspd (last visited Jan. 20, 2007).

36. Symposium, The Public Domain, 66 LAW \& CONTEMP. ProBs. 1 (James Boyle ed., Winter/Spring 2003).

37. See, e.g., William Fisher III, Promises to KeEP: TeChNology, LAW AND THE FUTURE OF ENTERTAINMENT (2004) (discussing alternative compensation systems).

38. See, e.g., Orphan Works, http://www.law.duke.edu/cspd/orphanworks.html (last visited Jan. 20, 2007) (exploring the effects of orphan works on intellectual property).

39. See, e.g., The Arts Project, http://www.law.duke.edu/cspd/artsproject/ (last visited Jan. 20, 2007) (exploring the effect of intellectual property on the arts).

40. To get some sense of the scope of these efforts, it is worth taking a look at the range of litigation and policy proposals being conducted by the three clinics discussed infra note 42 .

41. The Center's website can be found at http://cpg.genome.duke.edu/ (last visited Jan. 20, 2007).

42. See, for example, the work conducted by the Stanford Center on Internet and Society's Fair Use Project, http://cyberlaw.stanford.edu/taxonomy/term/374 (last visited Jan. 20, 2007), The Samuelson Law Technology and Public Policy Clinic at Boalt Hall, http://www.law.berkeley.edu/ clinics/samuelson/ (last visited Jan. 20, 2007), and the Samuelson-Glushko Intellectual Property Law Clinic at the Washington College of Law, http://www.wcl.american.edu/ipclinic/ (last visited Jan. 20, 2007). 
issues was only episodic. Its portfolio of litigation and public education on the subject is now nothing short of remarkable. ${ }^{43}$ Public Knowledge's valuable lobbying and education is another obvious example. ${ }^{44}$ Internationally, there are organizations with similar aims - such as the Open Rights Group in the United Kingdom. ${ }^{45}$ Organizing has also taken place around particular cases-such as Eldred v. Ashcroft, ${ }^{46}$ the challenge to the Sonny Bono copyright-term extension. ${ }^{47}$ Activity is not confined to the world of copyright. The Public Patent Foundation combats "patent creep" by exposing and challenging bad patents.

It would be remiss not to mention the international Access to Knowledge, or A2K movement, inspired by the work of Jamie Love. ${ }^{49}$ While its focus is on the kinds of issues represented by the access to medicines movement, it has made the idea of balance in intellectual property and the protection of the public domain one of its central components. Mr. Love, himself, is also the central figure behind the idea of a Research and Development Treaty, which would amend international trade agreements to make intellectual property merely one among a whole range of economic methods for stimulating innovation. ${ }^{50}$ His work has touched almost every single one of the movements discussed here.

The Access to Knowledge movement has many institutional variants. The "Development Agenda" at World Intellectual Property Organization (WIPO) put forward by India and Brazil includes similar themes, ${ }^{51}$ as do the Geneva Declaration $^{52}$ and the Adelphi Charter produced by the Royal Society for the Arts. ${ }^{53}$ History is full of wordy charters and declarations, of course. By

43. See Electronic Frontier Foundation, Intellectual Property, http://www.eff.org/IP/ (last visited Feb. 14, 2007).

44. Open Rights Group, http://www.openrightsgroup.org/ (last visited Feb. 14, 2007).

45. Public Knowledge, http://www.publicknowledge.org/ (last visited Feb. 14, 2007).

46. Eldred v. Ashcroft, 537 U.S. 186 (2003).

47. Once again, Professor Lessig had the central role as counsel for petitioners.

48. Public Patent Foundation, http://www.pubpat.org/ (last visited Feb. 14, 2007).

49. See Access to Knowledge, http://www.cptech.org/a2k/ (last visited Feb. 16, 2007); About James Love, http://www.cptech.org/jamie/ (last visited Feb. 16, 2007) (discussing some of Mr. Love's initiatives).

50. Tim Hubbard \& James Love, A New Trade Framework for Global Healthcare R\&D, 2 PLOS BIOLOLGY 1047 (2004), available at http://biology.plosjournals.org/perlserv/?request=get-pdf\&file= 10.1371_journal.pbio.0020052-L.pdf.

51. WIPO Development Agenda, http://www.cptech.org/ip/wipo/da.html (last visited Jan. 20, 2007).

52. The Geneva Declaration on the Future of the World Intellectual Property Organization, http://www.cptech.org/ip/wipo/futureofwipodeclaration.pdf (last visited Jan. 20, 2007). In the interests of full disclosure, I should note that I wrote a manifesto that formed the basis for earlier drafts of the Declaration. James Boyle, A Manifesto on WIPO and the Future of Intellectual Property, 2004 DUKE L. \& TECH. REV. 0009, 11, http://www.law.duke.edu/journals/dltr/articles/PDF/2004 DLTR0009.pdf.

53. The Adelphi Charter on Creativity, Innovation, and Intellectual Property, http://www.adelphicharter.org/ (last visited Jan. 20, 2007). The Charter was issued by the British Royal Society for the Encouragement of Arts, Manufacture and Commerce (RSA). For discussion of the Charter see James Boyle, Protecting the Public Domain, Educ. GuARDiAn Oct. 14, 2005, http://education.guardian.co.uk/higher/comment/story/0,9828,1591467,00.html; Free Ideas, 
themselves they mean little. Yet the level of public and media attention paid to them indicates that intellectual property policy is now of interest far beyond a narrow group of affected industries. To underscore this point, several major foundations have introduced intellectual property initiatives,${ }^{54}$ something that would have been inconceivable ten years ago.

Finally, to complete the analogy to the land trust, which Molly Van Houweling explores, we have organizations such as Creative Commons ${ }^{55}$ and the Free Software Foundation, ${ }^{56}$ which seek to create licensed "commons" in which freedoms are guaranteed. These replace the law's default rules with choices made by individuals, the effects of which are magnified by collective action. The end result is a zone of public freedom enabled by private choice.

If one looks at these institutions and actors and at the range of issues on which they focus-from software to drug patents, from the reverse engineering of software to access to archival records, the obvious question is "how did they overcome the collective action problem?" What ties together a critique of digital locks and the access to medicines movement? Again, I think the answer points to the usefulness of the environmental analogy. As I pointed out in "A Politics of Intellectual Property" together groups whose interests, considered at a lower level of abstraction, seemed entirely different-hunters and birdwatchers, anti-pollution protesters and conservation biologists. The idea of the "environment" literally created the "self-interest" or set of preferences that ties the movement together. The same is true here. Apparently disparate interests are tied together by the ideas of the protection of the public domain and of the importance of a balance between protection and freedom in the cultural and scientific ecology. As Amy Kapczynski points out in a fine recent manuscript, this process runs contrary to the economic literature on collective action..$^{58}$ Indeed, it appears to challenge, or at least stretch standard economic ideas about preferences. Economists generally assume preferences are simply given, individuals just have them and they are "exogenous" as to the legal system in the sense that they are unaffected

ECONOMIST, Oct. 13, 2005, at 68. Again, in the interests of full disclosure, I should note that I advised the RSA on these issues and was on the steering committee of the group that produced the Charter.

54. See, e.g., The MacArthur Foundation Program, Intellectual Property and the Public Domain, http://www.macfound.org/site/c.lkLXJ8MQKrH/b.943331/k.DA6/General_Grantmaking_Intellectual_ Property.htm (last visited Feb. 16, 2007) ("The General Program currently supports work in the area of intellectual property and the long-term protection of public domain as part of its support for multi-year initiatives in changing areas of special interest. Grants support new models, policy analysis, and public education designed to bring about balance between public and private interests concerning intellectual property rights in a digital era."). The Ford Foundation has a similar initiative. Frédéric Sultan, International Intellectual Property Initiative: I-Jumelage Ressources, Aug. 20, 2006, http://www.vecam.org/ijumelage/spip.php?article609.

55. Creative Commons, http://www.creativecommons.org (last visited Feb. 16, 2007).

56. Free Software Foundation, http://www.fsf.org (last visited Feb. 16, 2007).

57. Boyle, supra note 32, at 114.

58. Amy Kapczynski, The Access to Knowledge Movement and the New Politics of Intellectual Property Law (unpublished manuscript, on file with author). 
by the allocation of legal rights. ${ }^{59}$ The emergence of the movements and institutions I am describing here paints a different picture. The "preferences" are socially constructed, created through a collective process of debate and decision which shifts the level of abstraction upwards and, as Kapczynski perceptively notes, ${ }^{60}$ they are highly influenced by the legal categories and rights against which the groups involved initially defined themselves.

But even a broad range of initiatives and institutions would not, in and of themselves, be enough to produce results. One must convince people that one's arguments are good, one's institutional innovations necessary, and one's horror stories disturbing. Environmentalism has managed to win the battle for clarity - to make its points clearly enough that they ceased to be dismissed as "arcane" or technical, to overcome a neglect by the media, to articulate a set of ideas that are part of the concerns of any educated citizen. The other striking phenomenon of the last ten years is the migration of intellectual property issues off the law reviews or business pages and onto the front pages and the editorial pages. Blogs have been particularly influential. Widely read sites such as Slashdot $t^{61}$ and BoingBoing ${ }^{62}$ have multiple postings on intellectual property issues each day; some are rants, but others are at a level of sophistication that once would have been confined to academic discussion. Sites such as Groklaw ${ }^{63}$ bring collective intelligence to focus on perceived legal challenges to free and open-source software. The movement has been pronounced enough to generate its own reaction. The popular comics site $x k c d$ has strips critical of the Digital Millennium Copyright Act (DCMA) ${ }^{64}$ style-and-content protection but also a nerdily idyllic picture of a stick figure reclining under a tree and saying, "Sometimes I just can't get indignant about copyright law." ${ }^{65}$ Geek humor has always been an acquired taste.$^{66}$ But when the discussion of copyright minutiae has permeated the world of comics, something has changed. This is not to say that public awareness is anything like that in the environmental area. Still, the

59. Brett McDonnell, Endogenous Preferences and Welfare Evaluations, Minn. Legal Stud. Res. Paper No. 06-50 (2006), available at http://ssrn.com/abstract=933089 ("Economists and scholars in law and economics typically assume that preferences are exogenous; that is, that the policies being considered will not change the preferences of economic actors."). Professor McDonnell disagrees with the assumption, it is worth noting. Cass Sunstein makes exactly this point about the impact of environmental policy on preferences for environmental regulation. Cass R. Sunstein, Endogenous Preferences, Environmental Law, 22 J. LEGAL STUD. 217, 221-36 (1993); see also Samuel Bowles, Endogenous Preferences: The Cultural Consequences of Markets and Other Economic Institutions, $36 \mathrm{~J}$. ECON. LIT. 75 (reviewing the ways economic organization influences society).

60. Kapczynski, supra note 58.

61. News for Nerds: Stuff that Matters, http://www.slashdot.org (last visited Feb. 18, 2007).

62. A Directory of Wonderful Things, http://www.boingboing.net (last visited Feb. 18, 2007).

63. Groklaw, http://www.groklaw.net (last visited Feb. 18, 2007).

64. Pub. L. No. 105-304, 112 Stat. 2860 (1998) (codified as amended in scattered sections of 5, 17, 28, and 35 U.S.C.).

65. For the former see Content Protection, http://xkcd.com/c129.html (last visited Jan. 20, 2007), and Digital Rights Management, http://xkcd.com/c86.html (last visited Jan. 20, 2007). For the latter, see Copyright, http://xkcd.com/c14.html (last visited Jan. 20, 2007).

66. E.g., "There are 10 kinds of people in the world. Those who understand binary and those who do not." 
basic notions expressed in documents such as the Adelphi Charter ${ }^{67}$ - that intellectual property should be balanced, that rights should not be created or extended without evidence of their benefits, and that the burden of proof is on those who propose extensions-have achieved widespread currency.

\section{VI \\ CONCLUSION}

Metaphors and analogies do not make things happen by themselves. In the vast majority of cases, the environmental analogy merely provided an easy label to something that was happening anyway. Nevertheless, I think there are productive semantic, theoretical, economic, constituency-building, and organizational insights to be had in thinking about a cultural and scientific environmentalism. But as I pointed out ten years ago,

For some, the difference in seriousness of the two problems robs the analogy of its force. After all, environmental problems could actually destroy the biosphere and this is just, well, intellectual property. My response to this is partly that this is an analogy. I am comparing the form of the problems rather than their seriousness. Still, I have to say I believe that part of this reaction has to do with a failure to adjust to the importance that intellectual property has and is going to have in an information society. Again and again, one meets a belief that this is a technical issue with no serious human, political or distributional consequences. ${ }^{68}$

I went on to list issues indicating that this belief was wrong-ranging from access to medicines to effects on free speech, the increasing and unnecessary privatization of our common culture, and the crippling of the architecture of the open net. That does not make the $\mathrm{DMCA}^{69}$ or gene patenting the legal equivalent of global warming. But it does suggest that there are real problems of principle, of justice, and real human costs to getting these decisions wrong. It is my hope that such a point would come easier to people nowadays-some evidence that the "precautionary alarmism" I called for has born some fruit. The excellent papers gathered here-ranging from fan fiction to network building-reinforce that impression.

Yet perhaps the environmental movement still has one more lesson to offer us: humility. Movements are sometimes necessary in order to change habits of thought and patterns of policy. Yet they offer dogmas and blindnesses of their own. If the scholarship of the next ten years is to be more than an apologia for the industry proposal $d u$ jour, an uncritical cheering section for the public domain, or a dry collection of increasingly unrealistic economic models, then it needs to take seriously the kinds of methodological challenges in property theory and in economics that drew us to the subject in the first place. In those areas at least, our discipline is neither as sophisticated nor as critical as we like to pretend. The perennial fight with a crude maximalist political agenda has

67. Adelphi Charter, supra note 53.

68. Boyle, supra note 32, at 115 (first emphasis added).

69. Pub. L. No. 105-304, 112 Stat. 2860 (1998) (codified as amended in scattered sections of 5, 17, 28, and 35 U.S.C.). 
hurt more than the public domain. It has impoverished both sides of the theoretical debate as well. Let us hope that the next ten years will not replicate that history.

The work that most excites me today-both practical and theoretical-is constructive rather than critical. On the practical side, the attempt by organizations such as Creative Commons to make global, commons-based creativity a reality in areas ranging from science to education raises a multitude of questions. Does this force us to reconsider our views on copyright formalities? After all, both Creative Commons licenses and the General Public License that is at the base of the free-software movement depend on the instantaneous and costless applicability of copyright on fixation. Alternatively, should we see these licenses as merely a "second best" to an expanded public domain? Should there be a single unitary notion of what freedoms are guaranteed in the commons, or does our notion of freedom vary, depending on the type of creative work and the needs of both author and audience? $?^{70}$ To what

70. See, for example, the remarks of Richard Stallman:

"[P]eople have a tendency to disregard the differences between the various Creative Commons licenses, lumping them together as a single thing. That is as mixed-up as supposing San Francisco and Death Valley have similar weather because they're both in California.

Some Creative Commons licenses are free licenses; most permit at least noncommercial verbatim copying. But some, such as the Sampling Licenses and Developing Countries Licenses, don't even permit that, which makes them unacceptable to use for any kind of work. All these licenses have in common is a label, but people regularly mistake that common label for something substantial.

I no longer endorse Creative Commons. I cannot endorse Creative Commons as a whole, because some of its licenses are unacceptable. It would be self-delusion to try to endorse just some of the Creative Commons licenses, because people lump them together; they will misconstrue any endorsement of some as a blanket endorsement of all. I therefore find myself constrained to reject Creative Commons entirely."

Anupam Chander, Richard Stallman Critiques Creative Commons, http://www.chander.com/ 2006/03/richard_stallma.html (Mar. 18, 2006, 07:08) (quoting Richard Stallman). Compare these comments to the remarks of Lawrence Lessig:

Richard Stallman criticizes the one element that [the Developing Nations and Recombo Licenses] have in common - that while they both secure important freedoms, they also both forbid (for some groups at least) the right to 'copy' the underlying work. For him, that right is fundamental. And thus for him, any license that denies this fundamental freedom does not deserve the support of Creative Commons. He's thus asked us to either drop, or disassociate ourselves from, these two licenses.

It's extremely important first to clarify what this disagreement is not. Some of you will remember the battles between the 'free software' and 'open source software' movements. To some, those were battles between a movement that believed in values and a movement that believed in pragmatism. The disagreement between CC and Richard Stallman is not of that sort. It isn't pragmatism that drives us to adopt the Sampling and DevNat license. It is instead a different conception of value. CC will never offer licenses that secure just any freedom; we believe CC licenses should only secure important freedoms. But that's precisely what we believe these two licenses do-they secure important freedoms, even if they don't include the freedom to copy. That's not because the freedom to copy is not an important freedom in some contexts, or for some creators. But the freedom to copy is not an important freedom in all contexts-at least if it interferes with other important values.

For example, imagine you're a teacher in Nigeria. You want textbooks to teach Algebra to your Fulani speaking students. That you would have the right to copy a particular English textbook isn't really of much use to you. What you need is the right to translate that book. In that context, the derivative right is the critical one; the right to copy is unimportant. 
extent does the success of commons-based creativity depend on the development of business models that allow creators to donate certain aspects of their work to the commons while making money on other aspects of that work? Alternatively, does this path risk turning the commons into merely a collection of "loss-leaders," losing the sense of community and of delight in sharing that is so marked in sites such as Wikipedia? These and a host of other questions are sorely in need of both scholarly attention and community exploration-as Professor Van Houweling's paper points out. ${ }^{71}$

On the theoretical side, I think the best work has moved beyond a fascination with the second enclosure movement and the assault on the public domain. It is in work such as Yochai Benkler's Wealth of Networks ${ }^{72}$ that we can see the beginnings of a more sophisticated normative, economic, and anthropological notion of commons-based production. What efficiencies does it offer? What ideals of justice does it appeal to? Why is it that those involved with it seem to find in it the possibility that more labor-though never all labor-could have the features of the intensely satisfying, self-directed, play characteristic of the work of the artist and the academic (at least when not grading papers)? If the last ten years has involved the growth of both the theory and the organizational structure of an environmental movement for the public domain, it would be pleasant to imagine that the next ten years might continue the process into an investigation of "sharing nicely."

The same point could be made more generally. Our view is that the necessary freedoms in different domains of creativity are not necessarily the same. That music could be different from software, software different from film. And as we have done throughout this project, we have asked leaders in different fields who share the values of freedom to help us understand what values are important within those specific fields. Gil and Negativland know something about music. So when they say that the freedom to remix is critical even if the freedom to copy is not, it would take a great deal to persuade us they are wrong.

CC in Review: Lawrence Lessig on Important Freedoms, http://creativecommons.org/weblog/ entry/5719 (Dec. 7, 2005); see also Niva Elkin-Koren, What Contracts Can't Do: The Limits of Private Ordering in Facilitating a Creative Commons, 74 FORDHAM L. REV. 375 (2005) (explaining the limits of a creative commons).

71. Van Houweling, supra note 17.

72. BENKLER, supra note 14.

73. Yochai Benkler, Sharing Nicely: On Shareable Goods and the Emergence of Sharing as a Modality of Economic Production, 114 YALE L.J. 273 (2004). 